\title{
Important interaction between mirtazapine and ondansetron
}

Drug interaction in psychiatry is a clinically important issue, as it can cause side-effects and prevent adequate therapeutic effect. We report an unexpected interaction between the antidepressant mirtazapine and the antiemetic ondansetron in a 72 year old patient, weighing $68 \mathrm{~kg}$, with a height of $173 \mathrm{~cm}$. The patient, who gave his informed consent for anonymous publication, underwent electro-convulsive therapy (ECT), using a Thymatron System II, Somatics LLC with bitemporal electrode position, energy 40 repeated with $50 \%$ (corresponding charge: $257 \mathrm{mC}$, current: $0.92 \mathrm{~A}$, duration of stimulation $7 \mathrm{sec}$, frequency $40 \mathrm{~Hz}$ ) due to chronic severe depression. He was on pharmacological treatment with mirtazapine (45 mg daily) and venlafaxine (75 mg daily). The patient complained of severe nausea and vomiting after the first ECT session. Ondansetron, 4 mg was given without any clinical effect. The anaesthetic was of short duration, using a mask with etomidate $0.2 \mathrm{mg} / \mathrm{kg}$ repeated with $0.3 \mathrm{mg} / \mathrm{kg}$ and suxamethoniumchloride $1 \mathrm{mg} / \mathrm{kg}$ for short term muscle relaxation. However, the patient required administration of a further $8 \mathrm{mg}$ of ondansetron to secure sufficient relief of nausea. The procedure was better tolerated subsequently, as domperidone (D2-receptor blocker and antiemetic which does not penetrate blood brain barrier) was successfully used instead of ondansetron for the management of nausea

Mirtazapine is a so-called noradrenergic and specific

\begin{abstract}
serotonergic antidepressant with a half-life of 20-40 hours. Apart from its presynaptic antagonistic effect on alpha 2-receptors with release of both noradrenaline and serotonin - the postulated antidepressant effect - the compound antagonizes 5-HT2c, 5HT2a (sedation, sleep, appetite) and 5-HT3-receptors (nausea). ${ }^{1}$ Ondansetron is a relatively specific 5-HT3-antagonist used particularly in postoperative nausea and vomiting (PONV) in intravenous 4 mg doses. ${ }^{2}$ Ki-value (binding affinity of an inhibitor, ligand concentration which occupies $50 \%$ of a receptor) of ondansetron is $7.6 \mathrm{nMol}$, i. e. approximately 1/9 of the Ki-value of mirtazapine (about $70 \mathrm{nMol}$ ). ${ }^{3}$ The affinity of mirtazapine - with regard to normal antidepressant dose up to $45 \mathrm{mg}$ - was obviously not sufficient to block acute PONV, however, was able to inhibit immediate binding of ondansetron. This interaction may be of clinical relevance in depressive patients receiving long term mirta-zapine treatment who experience nausea following ECT treatment.
\end{abstract}

H Koch, D Nanev

Dept. of Psychiatry and Psychotherapy, HELIOS Clinic Aue, Aue, Germany

\section{References}

1. Holm KJ, Markham A. Mirtazapine: a review of its use in major depression. Drugs 1999; 57: 607-631.

2. Chaffee BJ, Tankanow RM. Ondansetron - the first of a new class of antiemetic agents. Clin Pharm 1991; 10: 430-446.

3. Hayashi H, Miwa Y, Ichikawa S, Yoda N, Miki I, Ishii A, et al. 5-HT3 receptor antagonists. 2.4-hydroxy-3-quinolinecarboxylic a-cid derivative. J Med Chem 1993; 36: 617-626.
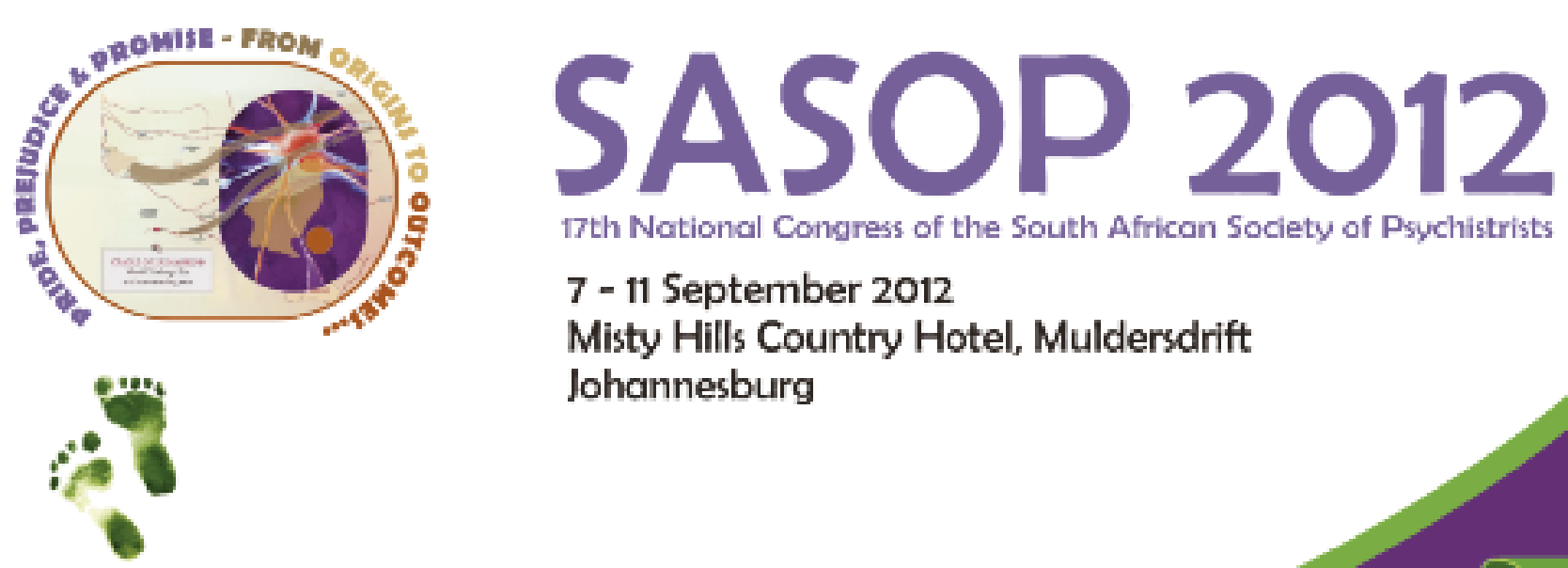

17th National Congress of the South African Society of Psychistrists

\section{7 - 11 September 2012 Misty Hills Country Hotel, Muldersdrift Johannesburg}

For further information please contact the congress organisers on: Londocor Event Management Tel: 427117684355 E-mail: sonjaQlondocor.co.za / yvonneGlondocor-co.za 